\title{
Study of Weak Acid Preservatives and Modified Atmosphere Packaging (MAP) on Mold Growth in Modal Agar System
}

\author{
Salah M. Hasan, Ramadan A. Abdolgader \\ Department of Food Science, Faculty of Agriculture, University of Omar Al-Mukhtar, Al-Beida, Libya. \\ Email: rabdolgader@yahoo.ca
}

Received February 21 ${ }^{\text {st }}$ 2012; revised April 27 ${ }^{\text {th }}, 2012$; accepted May $4^{\text {th }}, 2012$

\begin{abstract}
Inhibition of spoilage mold of common contaminant of bakery goods in modal agar system by potassium sorbate and calcium propionate in wide range of concentration (0 - $2000 \mathrm{ppm})$ at different $\mathrm{pH}(5.5$ - 7) was investigated. All Samples were examined daily for mold growth. Results showed that both potassium sorbate and calcium propionate can be used effectively to inhibit mold growth and the effectiveness of these preservatives is enhanced by increasing the concentration and decreasing the $\mathrm{pH}$. The effect of modified atmosphere packaging (MAP) comprised of $60 \%$ or $80 \% \mathrm{CO}_{2}$ (balance $\mathrm{N}_{2}$ ) and oxygen absorbents on the growth of mold was also studied on the agar system. The results indicated that mold growth was prevented up to 42 days in packs flushed with $60 \%$ or $80 \% \mathrm{CO}_{2}$ (balance $\mathrm{N}_{2}$ ). It was also evident that all samples did not show mold growth for $>40$ days when packaged in the presence of oxygen scavenger sachet.
\end{abstract}

Keywords: Mold; Potassium Sorbate; Calcium Sorbate; Preservatives; MAP

\section{Introduction}

Hurdle technology is now widely used in the design of new food products and the most suitable tool to develop new and safe products [1]. The main factors, such as antimicrobial agents, $\mathrm{pH}$, water activity (aw), and modified atmosphere packaging (MAP), influence the growth of the common spoilage molds of bakery goods [2]. Chemical preservatives are widely used to extend the shelf life and keep quality of bakery products, snack foods, pizza, meat, and cheese $[3,4]$. Sorbic acid, and its potassium salt have been used successfully to inhibit the growth of yeast, molds, and many bacteria in food [4]. Propionic acid and its salts are also highly effective mold inhibitors, without inhibiting yeast activity, and are used to prevent mold growth and ropiness in bakery goods.

From a food technologist's view point, water activity (aw) i.e., the amount of available water in food for microbial growth, is the most important parameter influencing the growth and metabolic activity of microorganisms [5,6]. Microbial spoilage and food poisoning occur if the aw of the substrate is favorable for the growth of microbial contaminants. Most microorganisms contaminating food grow at a high aw, while a few, such as osmophilic yeasts, require a low aw for growth. Thus, if aw decreases, only a few microorganisms are capable of growing in, and spoiling a specific food.
Modified atmosphere packaging (MAP) is becoming an increasingly popular method of food preservation. MAP, involving various gas mixtures of $\mathrm{CO}_{2}, \mathrm{O}_{2}$, and $\mathrm{N}_{2}$, has been used to extend both chemical and microbial shelf life of meat [7,8], peanuts and pecans [9], fish [10], rice, pasta [11,12], and bakery goods [13,14]. However, it has been used sparingly as a method for extending the mold free shelf life of baked. The aim of this study is to evaluate the effectiveness of preservatives, $\mathrm{pH}$ and MAP to control growth of the common contaminants of bakery goods Aspergillus niger, Pencillium expansum, and Pencillium notatum, in model agar systems.

\section{Materials and Methods}

\subsection{Microorganisms and Inoculum Preparation Selecting a Template}

Mold strains of Aspergillus niger (16404), Pencillium notatum (10108), and Pencillium expansum (7861) were obtained from the American Type Culture Collection (ATCC). Cultures were grown on Potato Dextrose Agar (PDA) (Difco, Michigan, USA) at $27^{\circ} \mathrm{C}$ and transferred every three weeks to ensure viability. The inoculum was prepared by growing molds on PDA at $27^{\circ} \mathrm{C}$ for 5 to 7 days until sporulation had occurred. Mold spores were harvested by dislodging spores into $9 \mathrm{ml}$ of $0.1 \%(\mathrm{v} / \mathrm{v})$ 
peptone water containing 1 - 2 drops of Tween 80 to prevent spore clumping. Spores were enumerated using an Improved Neubauer haemacytometer (Fisher Scientific). Appropriate dilutions of each stock solution were made using $0.1 \%$ peptone water to give working suspensions containing an inoculum level of $~ 104$ spores/ml throughout this study.

\subsection{Preparation of Potassium Sorbate and Calcium Propionate}

A $10 \%(\mathrm{w} / \mathrm{v})$ stock solution of each preservative was prepared by dissolving $10 \mathrm{~g}$ of potassium sorbate (KS) and calcium propionate (CP) in $100 \mathrm{ml}$ water then stirring for approximately $2 \mathrm{~min}$. The preservatives were then filtered and sterilized by using a seitz filtration unit (Nalge Company, Sybron International, NY, USA). Each preservative solution was stored in a dark bottle under refrigeration until use.

\subsection{Antimicrobial Effect of Preservatives at Various pH Levels}

Experimental flasks were filled with appropriate amounts of Potato Dextrose Agar (Difco, Michigan, USA), sterilized by autoclaving at $121^{\circ} \mathrm{C}$ for $15 \mathrm{~min}$, then cooled in a water bath to $50^{\circ} \mathrm{C}$. The $\mathrm{pH}$ of the cooled media was then adjusted to $\mathrm{pH} 5,5.5,6.0$ and 7.0 using $1 \mathrm{~N} \mathrm{NaOH}$ or $1 \mathrm{~N}$ lactic acid. The $\mathrm{pH}$ of the media was checked using a previously calibrated $\mathrm{pH}$ meter (Model 220, Corning Glass NY) with an agal filled polymer body combined electrode with agal $\mathrm{Ag} / \mathrm{AgCl}$ reference (Fisher Scientific, Model (13-620-104). Appropriate amounts of each stock solution of potassium sorbate, calcium propionate, and equal mixtures of each stock solution were then added aseptically to the $\mathrm{pH}$ adjusted media to give final concentrations ranging from $0-2000 \mathrm{ppm}$ at increments of 250 ppm i.e., levels commonly used comercially as shown in Tables 1-3 respectively. The media was then dispensed into petri dishes $(150 \times 150 \mathrm{~mm})$ and allowed to solidify in a sterile laminar flow cabinet (Labconco Corporation). Plates were inoculated in triplicate at 5 points with $25 \mu$ l of each mold suspension using an automatic pipette (Fisher Scientific). Inoculated plates were incubated aerobically at $25^{\circ} \mathrm{C}$ and checked daily for visible signs of mold growth.

\subsection{Effect of MAP on Mold Growth in an Agar System}

To determine the effect of MAP on the growth of A. niger, $P$. notatum, and $P$. expansum, PDA plates were prepared and sterilized according to the manufacture's specifications. Upon cooling, the $\mathrm{pH}$ of all plates were adjusted to
Table 1. Antimicrobial effect of potassium sorbate (KS) on mold growth in PDA at $\mathrm{pH} 5.0$ \& $25^{\circ} \mathrm{C}$.

\begin{tabular}{cccc}
\hline \multirow{2}{*}{$\begin{array}{c}\text { Level of KS } \\
(\text { ppm })\end{array}$} & \multicolumn{3}{c}{ Days to visible mold growth } \\
\cline { 2 - 4 } & A. niger & P. notatum & P. expansum \\
\hline 0 & $1^{\mathrm{e}}$ & $1^{\mathrm{c}}$ & $2^{\mathrm{c}}$ \\
250 & $2^{\mathrm{d}}$ & $4^{\mathrm{b}}$ & $10^{\mathrm{b}}$ \\
500 & $2^{\mathrm{d}}$ & $\mathrm{NG}$ & $\mathrm{NG}$ \\
750 & $3.5^{\mathrm{c}}$ & $\mathrm{NG}$ & $\mathrm{NG}$ \\
1000 & $5^{\mathrm{b}}$ & $\mathrm{NG}$ & $\mathrm{NG}$ \\
1500 & $\mathrm{NG}$ & $\mathrm{NG}$ & NG \\
1750 & $\mathrm{NG}$ & $\mathrm{NG}$ & NG \\
2000 & $\mathrm{NG}$ & $\mathrm{NG}$ & NG \\
\hline
\end{tabular}

NG: No growth $(>40 \mathrm{~d})$.

Table 2. Antimicrobial effect of potassium sorbate (KS) on mold growth in PDA at pH $5.5 \& 25^{\circ} \mathrm{C}$.

\begin{tabular}{cccc}
\hline \multirow{2}{*}{$\begin{array}{c}\text { Level of KS } \\
(\text { ppm })\end{array}$} & \multicolumn{3}{c}{ Days to visible mold growth } \\
\cline { 2 - 4 } & A. niger & P. notatum & P. expansum \\
\hline 0 & $1^{\mathrm{f}}$ & $1^{\mathrm{e}}$ & $2^{\mathrm{c}}$ \\
250 & $2^{\mathrm{e}}$ & $2^{\mathrm{d}}$ & $7^{\mathrm{b}}$ \\
500 & $2^{\mathrm{e}}$ & $3^{\mathrm{c}}$ & NG \\
750 & $3^{\mathrm{d}}$ & $4^{\mathrm{b}}$ & NG \\
1000 & $4^{\mathrm{c}}$ & $4^{\mathrm{b}}$ & NG \\
1500 & $5^{\mathrm{b}}$ & NG & NG \\
1750 & $6^{\mathrm{a}}$ & NG & NG \\
2000 & $6^{\mathrm{a}}$ & NG & NG \\
\hline
\end{tabular}

Table 3. Antimicrobial effect of potassium sorbate (KS) on mold growth in PDA at pH 6.0 \& $25^{\circ} \mathrm{C}$.

\begin{tabular}{cccc}
\hline \multirow{2}{*}{$\begin{array}{c}\text { Level of KS } \\
\text { ppm }\end{array}$} & \multicolumn{3}{c}{ Days to visible mold growth } \\
\cline { 2 - 4 } & A. niger & P. notatum & P. expansum \\
\hline 0 & $1^{\mathrm{b}}$ & $1^{\mathrm{d}}$ & $2^{\mathrm{c}}$ \\
250 & $1^{\mathrm{b}}$ & $1^{\mathrm{d}}$ & $5^{\mathrm{b}}$ \\
500 & $1^{\mathrm{b}}$ & $1^{\mathrm{d}}$ & NG \\
750 & $1^{\mathrm{b}}$ & $1^{\mathrm{d}}$ & NG \\
1000 & $2^{\mathrm{a}}$ & $2^{\mathrm{c}}$ & NG \\
1500 & $2^{\mathrm{a}}$ & $3^{\mathrm{b}}$ & NG \\
1750 & $2^{\mathrm{a}}$ & $4^{\mathrm{a}}$ & NG \\
2000 & $2^{\mathrm{a}}$ & $4^{\mathrm{a}}$ & NG \\
\hline
\end{tabular}


7.0 by adding appropriate amounts of $1 \mathrm{~N}$ lactic acid or 1 $\mathrm{N} \mathrm{NaOH}$ to the medium. Triplicate plates were then inoculated with each of the mold suspensions as described previously. All plates were packaged in $210 \times$ $210 \mathrm{~mm}$ high gas barrier Cryovac bags (oxygen transmission rate $3-6 \mathrm{~cm}^{3} /$ day at $4.4^{\circ} \mathrm{C}, 0 \% \mathrm{RH}$ ). One set of packages was flushed with levels of $\mathrm{CO}_{2}$ ranging from $60 \%$ to $80 \%$ (balance $\mathrm{N}_{2}$ ) using a Multivac chamber type, heat seal packaging machine (Model KM100-3 M). The proportion of gases was regulated by a Smith's level gas mixer (Tescom, Minneapolis, MN) to give the desired proportion of gases in the package headspace. In the second set of packages, the atmosphere was modified using an Ageless 100 type FX oxygen absorbent (Mitsubishi Gas Co., Tokyo, Japan). Absorbents (1 or 2) were taped to the inside of each package prior to heat sealing with an impulse heat sealer. All packages were incubated at $25^{\circ} \mathrm{C}$ and checked daily for visible signs of mold growth. Headspace gas was monitored in all packages using a previously calibrated portable oxygen analyzer (Teledyne Analytical Instrument, City of Industry, CA, USA).

\subsection{Headspace Gas Analysis}

Samples were analyzed for changes in headspace gas when visible signs of mold growth were observed. Gas samples were withdrawn using a $0.5 \mathrm{ml}$ gas tight Pressure-lok syringe (Precision Sampling Corp., Baton Rouge, La.) through silicone seals attached to the package exterior. The gas samples were injected into a Varian gas chromatograph (Model 3400, Varian Canada Inc.) equipped with a thermal conductivity detector (TCD) and using Porapak Q (80 - 100 mesh) and Molecular Sieve 5A (80 - 100 mesh) columns in series (Supelco Canada Ltd.). The carrier gas was helium set at a flow rate of 30 $\mathrm{ml} / \mathrm{min}$. The column oven was set at $80^{\circ} \mathrm{C}$, the injector at $100^{\circ} \mathrm{C}$ and the detector filament at $150^{\circ} \mathrm{C}$. Peaks were recorded using a Hewlett Packard integrator (Model 3390A, Hewlett Packard Co., Avondale, PA).

\subsection{Statistical Analysis}

All data represent the mean of three replications per treatment and evaluation. Analysis of variance (ANOVA), followed by least significant difference (LSD) compareson test for means with significant level of $\mathrm{P}<0.05$ was performed on the using SPSS (Windows 2003, Statistical Analysis).

\section{Results and Discussion}

\subsection{Antimicrobial Effect of Potassium Sorbate (KS)}

The effect of various concentrations of KS (0 - 2000 ppm) on the growth of $A$. niger, $P$. notatum, and $P$. expansum on PDA at pH 5.0, 5.5, 6.0 and 7.0 at $25^{\circ} \mathrm{C}$ are shown in Tables 1-4, respectively. At $\mathrm{pH} 5.0$, mold growth was observed in control samples after 1 - 2 d respectively (Table 1). Potassium sorbate (250 ppm) inhibited mold growth from 2 to 10 days, depending on mold species, with $A$. niger being more resistant to KS than either $P$. notatum and $P$. expansum. While the growth of the two latter species was inhibited for up to 40 days by concentrations of KS as low as $500 \mathrm{ppm}$, at least twice this concentration (1250 - $1500 \mathrm{ppm})$ was required for the complete inhibition of A. niger at $\mathrm{pH}$ 5.0. These results are in agreement with the studies of [15] who also observed that $A$. niger was more resistant to mold inhibitors than other mold species.

Similar trends were observed for $A$. niger, $P$. notatum, and $P$. expansum on PDA at $\mathrm{pH} 5.5$ and $25^{\circ} \mathrm{C}$, While growth of both $P$. notatum and $P$. expansum occurred after 2 - 5 days with low concentrations of KS (250 $1000 \mathrm{ppm}$ ) at $\mathrm{pH} 5.5$, growth of both molds was completely inhibited for $>40$ days using higher levels of KS in the growth media (Table 2).

The response of mold growth on agar media containing 0 - $2000 \mathrm{ppm} \mathrm{KS}$ at $\mathrm{pH} 6.0$ is shown in Table 3. At concentrations of $250-1000 \mathrm{ppm} \mathrm{KS}$, growth of A. niger was visible after 1 day, i.e., similar to control samples. However, when the concentration of potassium sorbate was increased to $1000-2000 \mathrm{ppm}$, growth of A. niger was only inhibited for 2 days at $\mathrm{pH}$ 6.0. Growth of $P$. notatum occurred on PDA after $1 \mathrm{~d}$ at $\mathrm{pH} 6.0$ in the both control samples and in plates containing $250-1000$ ppm KS. When the level of KS increased to $1500-2000$ ppm, growth was visible only after $3-4$ days at $\mathrm{pH}$ 6.0. P. expansum was more sensitive to all concentrations of KS in the media. While growth was inhibited for $5 \mathrm{~d}$ at low concentrations of KS, growth was completely inhibited in plates containing $>500 \mathrm{ppm}$ for $>40$ days at $\mathrm{pH} 6.0$. These results confirmed the early observations of [16] who reported that sorbate, in contrast to the other preservatives acids, can be used for the preservation of food with a relatively high $\mathrm{pH}$ value. However, the growth of A. niger, P. notatum, and P. expansum on PDA at $\mathrm{pH} 7.0$ was visible after 1 - 2 days on PDA at all concentrations of KS under investigation (Table 4).

It is evident from all Tables 1-4 that the activity of potassium sorbate increased as $\mathrm{pH}$ decreased. With the exception of $A$. niger, mold growth was completely inhibited in an agar system containing $>500 \mathrm{ppm} \mathrm{KS}$ at $\mathrm{pH}$ 5.0. However, three times this concentration of KS (1500 $\mathrm{ppm}$ ) was required to completely inhibit the growth of $A$. niger at this $\mathrm{pH}$. Similar trends were observed at both $\mathrm{pH}$ 5.5 and 6.0 indicating that inhibition was due to the combined effect of $\mathrm{pH}$ and sorbate concentrations. These 
Table 4. Antimicrobial effect of potassium sorbate (KS) on mold growth in PDA at $\mathrm{pH} 7.0 \& 25^{\circ} \mathrm{C}$.

\begin{tabular}{cccc}
\hline \multirow{2}{*}{$\begin{array}{c}\text { Level of KS } \\
\text { ppm }\end{array}$} & \multicolumn{3}{c}{ Days to visible mold growth } \\
\cline { 2 - 4 } & A. niger & P. notatum & P. expansum \\
\hline 0 & $1^{\mathrm{a}}$ & $1^{\mathrm{a}}$ & $2^{\mathrm{a}}$ \\
250 & $1^{\mathrm{a}}$ & $1^{\mathrm{a}}$ & $2^{\mathrm{a}}$ \\
500 & $1^{\mathrm{a}}$ & $1^{\mathrm{a}}$ & $2^{\mathrm{a}}$ \\
750 & $1^{\mathrm{a}}$ & $1^{\mathrm{a}}$ & $2^{\mathrm{a}}$ \\
1000 & $1^{\mathrm{a}}$ & $1^{\mathrm{a}}$ & $2^{\mathrm{a}}$ \\
1500 & $1^{\mathrm{a}}$ & $1^{\mathrm{a}}$ & $2^{\mathrm{a}}$ \\
1750 & $1^{\mathrm{a}}$ & $1^{\mathrm{a}}$ & $2^{\mathrm{a}}$ \\
2000 & $1^{\mathrm{a}}$ & $1^{\mathrm{a}}$ & $2^{\mathrm{a}}$ \\
\hline
\end{tabular}

results agree with those observed by [17] who found that potassium sorbate was more effective against the molds at lower $\mathrm{pH}$ values $(<6.5)$. Growth of $P$. expansum was completely inhibited in agar at $\mathrm{pH}$ 5.0, 5.5 and 6.0 and at concentrations of KS of $500 \mathrm{ppm}$, indicating that it was the most sensitive mold to KS.

Statistical analysis of the data showed that $\mathrm{pH}$ had a highly significant effect $(\mathrm{P}<0.05)$ on the antimicrobial activity of potassium sorbate. The results showed that the antimicrobial activity of potassium sorbate at $\mathrm{pH} 5.0$ against both $A$. niger and $P$. notatum was significantly different compared to $\mathrm{pH} 5.5,6.0$, and 7.0. It is evident that $\mathrm{pH}$ played a significant role on the activity of potassium sorbate; however this effect is dependent on other interrelated factors, such as levels of sorbate and species of microorganism. This study agrees with the results of $[18,19]$ who reported that the initial number and type of mold present in food will influence the ability of potassium sorbate to prevent microbial growth and spoilage. Consequently, potassium sorbate should not be used for preservation when high mold counts are expected, since a high level of mold contamination can metabolize potassium sorbate thus reducing its fungistatic effect. This may explain why some molds in this study grew in the presence of high concentrations of potassium sorbate. Therefore, it is critical to use potassium sorbate in goods produced under proper manufacturing practices and with the appropriate $\mathrm{pH}$ value.

The concentration of potassium sorbate also had a highly significant effect $(\mathrm{P}<0.05)$ on mold growth. A comparison between concentrations showed that a level of $1500 \mathrm{ppm}$ potassium sorbate would be the most effecttive level to inhibit mold growth. It is evident from the results obtained in this study that the minimal inhibitory (MIC) concentration of potassium sorbate for inhibiting mold growth varied with mold species and $\mathrm{pH}$. The MIC in this study of potassium sorbate against test molds ranged between 750 to $1500 \mathrm{ppm}$ at $\mathrm{pH} 6.0$ and $500-$ $1500 \mathrm{ppm}$, at $\mathrm{pH} 5.0$ and 5.5. The results indicated that the MIC of potassium sorbate at $\mathrm{pH} 5.0$ was slightly contrary to the observations of [20], who reported that the minimum antimicrobial activity of sorbate was $800 \mathrm{ppm}$ at $\mathrm{pH}$ 5.0. However, [21] observed that the MIC of potassium sorbate was in the range between $100-1000$ ppm and was dependent on the $\mathrm{pH}$ of the substrate, types and numbers of molds, as well as their environmental factors.

\subsection{Antimicrobial Effect of Calcium Propionate}

The effect of various concentrations of $\mathrm{CP}$ on the growth of $A$. niger, $P$. notatum, and $P$. expansum on PDA at various $\mathrm{pH}$ levels are shown in Tables 5-8 respectively. As shown in Table 5, low concentrations of CP were unable to inhibit mold growth. At pH 5.0, growth of $A$. niger was visible after 1day on PDA containing 250 $750 \mathrm{ppm}$ of CP i.e., similar to control plates. However, the effectiveness of calcium propionate was proportional to its concentration in the agar medium. At higher concentrations of CP (1000 - $2000 \mathrm{ppm})$ growth of A. niger was delayed for 2 - $4 \mathrm{~d}$ respectively.

The response of $P$. notatum on PDA to various concentrations of $\mathrm{CP}$ at $\mathrm{pH} 5.0$ was similar to that observed for $P$.expansum. For Penicillium species, CP nearly doubled the time for visible growth compared to A. niger. At concentrations ranging from $1000-2000 \mathrm{ppm}$, growth of $P$. notatum was inhibited for $4-10$ days respectively. Similar results were observed for $P$. expansum. However, at higher concentrations of CP (1750 - $2000 \mathrm{ppm})$ growth of this mold was inhibited for 11 - 13 days. These results confirmed that higher concentrations of CP had a more inhibitory effect on mold growth and that Penicillium species were more sensitive to these higher concentrations than Aspergillus species i.e., similar to previous observations with potassium sorbate.

In all cases, growth of $A$. niger, $P$. notatum, and $P$. expansum occurred after 1 - 2 days respectively on PDA, regardless of the levels of $\mathrm{CP}$ in the media. These results confirm that both the inhibitory effect of CP and KS is also $\mathrm{pH}$ dependent with the inhibitory effect being enhanced at lower $\mathrm{pH}$ values.

It is apparent that the activity of $\mathrm{CP}$ increased as $\mathrm{pH}$ decreased. Growth of $A$. niger was visible after 4 days even with high concentration of CP (2000 ppm) on PDA at $\mathrm{pH} 5.0$ (Table 5). However, growth occurred after only 1 day at all CP concentrations at pH 5.5, 6.0 and 7.0, respectively (Tables 6-8).

Complete inhibition of Pencillium species was observed at pH 5.0 and at high concentrations of CP (2000 ppm). At pH 5.5, 6.0 and 7.0, similar levels of CP were 
Table 5. Antimicrobial effect of calcium propionate (CP) on mold growth on PDA at $\mathrm{pH} 5.0$ \& $25^{\circ} \mathrm{C}$.

\begin{tabular}{cccc}
\hline \multirow{2}{*}{$\begin{array}{c}\text { Level of CP } \\
\text { ppm }\end{array}$} & \multicolumn{3}{c}{ Days to visible mold growth } \\
\cline { 2 - 4 } & A. niger & P. notatum & P. expansum \\
\hline 0 & $1^{\mathrm{d}}$ & $1^{\mathrm{g}}$ & $2^{\mathrm{f}}$ \\
250 & $1^{\mathrm{d}}$ & $1^{\mathrm{g}}$ & $2^{\mathrm{f}}$ \\
500 & $1^{\mathrm{d}}$ & $2^{\mathrm{f}}$ & $3^{\mathrm{e}}$ \\
750 & $1^{\mathrm{d}}$ & $3^{\mathrm{e}}$ & $3^{\mathrm{e}}$ \\
1000 & $2^{\mathrm{c}}$ & $4^{\mathrm{d}}$ & $5^{\mathrm{d}}$ \\
1500 & $3^{\mathrm{b}}$ & $8^{\mathrm{c}}$ & $8^{\mathrm{c}}$ \\
1750 & $4^{\mathrm{a}}$ & $9^{\mathrm{b}}$ & $11^{\mathrm{b}}$ \\
2000 & $4^{\mathrm{a}}$ & $10^{\mathrm{a}}$ & $13^{\mathrm{a}}$ \\
\hline
\end{tabular}

Table 6. Antimicrobial effect of calcium propionate (CP) on mold growth on PDA at $\mathrm{pH} 5.5 \& 25^{\circ} \mathrm{C}$.

\begin{tabular}{|c|c|c|c|}
\hline \multirow{2}{*}{$\begin{array}{c}\text { Level of CP } \\
\text { ppm }\end{array}$} & \multicolumn{3}{|c|}{ Days to visible mold growth } \\
\hline & A. niger & P. notatum & P. expansum \\
\hline 0 & $1^{\mathrm{a}}$ & $1^{\mathrm{a}}$ & $2^{\mathrm{a}}$ \\
\hline 250 & $1^{\mathrm{a}}$ & $1^{\mathrm{a}}$ & $2^{\mathrm{a}}$ \\
\hline 500 & $1^{\mathrm{a}}$ & $1^{\mathrm{a}}$ & $2^{\mathrm{a}}$ \\
\hline 750 & $1^{\mathrm{a}}$ & $1^{\mathrm{a}}$ & $2^{\mathrm{a}}$ \\
\hline 1000 & $1^{\mathrm{a}}$ & $1^{\mathrm{a}}$ & $2^{\mathrm{a}}$ \\
\hline 1500 & $1^{\mathrm{a}}$ & $1^{\mathrm{a}}$ & $2^{\mathrm{a}}$ \\
\hline 1750 & $1^{\mathrm{a}}$ & $1^{\mathrm{a}}$ & $2^{\mathrm{a}}$ \\
\hline 2000 & $1^{\mathrm{a}}$ & $1^{\mathrm{a}}$ & $2^{\mathrm{a}}$ \\
\hline
\end{tabular}

Table 7. Antimicrobial effect of calcium propionate (CP) on mold growth on PDA at pH 6.0 \& $25^{\circ} \mathrm{C}$.

\begin{tabular}{cccc}
\hline \multirow{2}{*}{$\begin{array}{c}\text { Level of CP } \\
\text { ppm }\end{array}$} & \multicolumn{3}{c}{ Days to visible mold growth } \\
\cline { 2 - 4 } & A. niger & P. notatum & P. expansum \\
\hline 0 & $1^{\mathrm{a}}$ & $1^{\mathrm{a}}$ & $2^{\mathrm{a}}$ \\
250 & $1^{\mathrm{a}}$ & $1^{\mathrm{a}}$ & $2^{\mathrm{a}}$ \\
500 & $1^{\mathrm{a}}$ & $1^{\mathrm{a}}$ & $2^{\mathrm{a}}$ \\
750 & $1^{\mathrm{a}}$ & $1^{\mathrm{a}}$ & $2^{\mathrm{a}}$ \\
1000 & $1^{\mathrm{a}}$ & $1^{\mathrm{a}}$ & $2^{\mathrm{a}}$ \\
1500 & $1^{\mathrm{a}}$ & $1^{\mathrm{a}}$ & $2^{\mathrm{a}}$ \\
1750 & $1^{\mathrm{a}}$ & $1^{\mathrm{a}}$ & $2^{\mathrm{a}}$ \\
2000 & $1^{\mathrm{a}}$ & $1^{\mathrm{a}}$ & $2^{\mathrm{a}}$ \\
\hline
\end{tabular}

Table 8: Antimicrobial effect of calcium propionate (CP) on mold growth in PDA at $\mathrm{pH} 7.0$ \& $25^{\circ} \mathrm{C}$.

\begin{tabular}{cccc}
\hline \multirow{2}{*}{$\begin{array}{c}\text { Level of CP } \\
\text { ppm }\end{array}$} & \multicolumn{3}{c}{ Days to visible mold growth } \\
\cline { 2 - 4 } & A. niger & P. notatum & P. expansum \\
\hline 0 & $1^{\mathrm{a}}$ & $1^{\mathrm{a}}$ & $2^{\mathrm{a}}$ \\
250 & $1^{\mathrm{a}}$ & $1^{\mathrm{a}}$ & $2^{\mathrm{a}}$ \\
500 & $1^{\mathrm{a}}$ & $1^{\mathrm{a}}$ & $2^{\mathrm{a}}$ \\
750 & $1^{\mathrm{a}}$ & $1^{\mathrm{a}}$ & $2^{\mathrm{a}}$ \\
1000 & $1^{\mathrm{a}}$ & $1^{\mathrm{a}}$ & $2^{\mathrm{a}}$ \\
1500 & $1^{\mathrm{a}}$ & $1^{\mathrm{a}}$ & $2^{\mathrm{a}}$ \\
1750 & $1^{\mathrm{a}}$ & $1^{\mathrm{a}}$ & $2^{\mathrm{a}}$ \\
2000 & $1^{\mathrm{a}}$ & $1^{\mathrm{a}}$ & $2^{\mathrm{a}}$ \\
\hline
\end{tabular}

unable to control mold growth. The results show that molds may have the ability to develop resistance to $\mathrm{CP}$, particularly at higher $\mathrm{pH}$ levels. Similar results were observed by [22] who reported that while calcium propionate exhibited antimycotic activity, its use was limited to lower $\mathrm{pH}$ food since no antimycotic activity was observed in food with neutral or near neutral $\mathrm{pH}$ values.

Statistical analysis of the data showed that $\mathrm{pH}$ had significant effect $(\mathrm{P}<0.05)$ on the activity of CP. A comparison between the $\mathrm{pH}$ levels investigated showed that $\mathrm{pH} 5.0$ was the most effective $\mathrm{pH}$ for the antimicrobial action of CP. This is again due to the greater amount of undissociated $\mathrm{CP}$ at more acidic $\mathrm{pH}$ levels.

The concentration of $\mathrm{CP}$ also had significant effect (P $<0.05)$ on mold growth. At pH 5.0, higher levels of CP (1000 - $2000 \mathrm{ppm}$ ) had a more significant effect on mold growth compared to lower levels at all $\mathrm{pH}$ values under investigation. These results confirm the earlier finding of [23] who observed that the minimum inhibitory concentration of calcium propionate in PDA required to prevent the growth of $A$. niger and $P$. notatum at $\mathrm{pH} 6.0$ was 4000 ppm and 3000 ppm respectively. Acott and Labuza [24] reported that, if foods were higher in $\mathrm{pH}$, more calcium propionate than the FDA allowance of 2000 ppm would be necessary for preservation. Furthermore, these results clearly indicate that, on a weight to weight basis, $\mathrm{KS}$ is a far more effective antimycotic agent against the molds tested in this study.

\subsection{Effect of MAP on Mold Growth in Model Agar System at pH 7.0 and $25^{\circ} \mathrm{C}$}

The effect of modified atmosphere packaging on the growth of A. niger, P. notatum, and P. expansum in PDA plates at $\mathrm{pH} 7.0$ are shown in Tables 9-11. The percentage of $\mathrm{O}_{2}, \mathrm{CO}_{2}$ and $\mathrm{N}_{2}$ in the package headspace was the 
Table 9. Effect of gas packaging on the growth $A$. niger at pH 7.0 and $25^{\circ} \mathrm{C}$.

\begin{tabular}{ccccc}
\hline \multirow{2}{*}{$\begin{array}{c}\text { Levels of } \\
\mathrm{CO}_{2}(\%)\end{array}$} & $\begin{array}{c}\text { Days to visible } \\
\text { growth of A. niger }\end{array}$ & \multicolumn{3}{c}{ *Headspace gas composition (\%) } \\
\cline { 3 - 5 } Air & 1 & 1.0 & 20.4 & 78.6 \\
60 & 5 & 50 & 2.0 & 48 \\
80 & 8 & 69.8 & 3.4 & 26.8 \\
\hline
\end{tabular}

All values are the average of triplicates. *At onset of mold growth.

Table 10. Effect of gas packaging on the growth of $P$. notatum growth at $\mathrm{pH} 7.0 \& 25^{\circ} \mathrm{C}$.

\begin{tabular}{ccccc}
\hline \multirow{2}{*}{$\begin{array}{c}\text { Levels of } \\
\mathrm{CO}_{2}(\%)\end{array}$} & $\begin{array}{c}\text { Days to visible } \\
\text { growth of }\end{array}$ & \multicolumn{3}{c}{ *Headspace gas composition (\%) } \\
\cline { 3 - 5 } & P. notatum & $\mathrm{CO}_{2}$ & $\mathrm{O}_{2}$ & $\mathrm{~N}_{2}$ \\
\hline Air & 1 & 1.5 & 18.8 & 79.7 \\
60 & 7 & 49.2 & 1.7 & 49.1 \\
80 & 10 & 69.8 & 2.2 & 28 \\
\hline
\end{tabular}

All values are the average of triplicates. ${ }^{*}$ At onset of mold growth.

Table 11. Effect of gas packaging on the growth of $P$. expansum growth at $\mathrm{pH} 7.0 \& 25^{\circ} \mathrm{C}$.

\begin{tabular}{ccccc}
\hline \multirow{2}{*}{$\begin{array}{c}\text { Levels of } \\
\mathrm{CO}_{2}(\%)\end{array}$} & $\begin{array}{c}\text { Days to visible } \\
\text { growth of } \\
\text { P. expansum }\end{array}$ & \multicolumn{3}{c}{${ }^{*}$ Headspace gas composition (\%) } \\
\cline { 3 - 5 } & 1 & 1.5 & 19.7 & 78.8 \\
\hline Air & 30 & 39 & 1.5 & 59.5 \\
60 & $\mathrm{CO}_{2}$ & $\mathrm{O}_{2}$ & $\mathrm{~N}_{2}$ \\
80 & & 45 & 2.5 & 52.5 \\
\hline
\end{tabular}

All values are the average of triplicates. ${ }^{*}$ At onset of mold growth. ${ }^{* *} \mathrm{NG}=$ No growth after (42 d).

headspace gas composition of the packages when growth of $A$. niger, $P$. notatum, and $P$. expansum was visible.

Addition of $\mathrm{CO}_{2}$ (approximately 60\%) inhibited the growth of $A$. niger, with growth appearing within 5 days in all plates. This agrees with previous studies showing growth of $A$. niger in agar plates packaged in $60 \% \mathrm{CO}_{2}$ occurring within 5 days [25]. When plates were packaged in higher $\mathrm{CO}_{2}$ levels (approximately $80 \%$ ) growth appeared after 8 days at $25^{\circ} \mathrm{C}$ (Table 9).

Similar results were observed for both $P$. notatum and $P$. expansum. Growth of $P$. notatum was observed after 7 days in PDA plates packaged in $60 \% \mathrm{CO}_{2}$, while growth was delayed for 10 days in plates packaged in approximately $80 \% \mathrm{CO}_{2}$ (Tables 10). However, growth of $P$. expansum was delayed for $\sim 30$ days in plates packaged in $60 \% \mathrm{CO}_{2}$, while no growth appeared in plates packaged in $80 \% \mathrm{CO}_{2}$ (Table 11). Several studies have reported that a concentration of $60 \% \mathrm{CO}_{2}$ has been used to extend the mold free shelf life of bakery goods [15]. Therefore, the earlier appearance of mold growth in this study maybe due to residual $\mathrm{O}_{2}$ in the package headspace. The level of residual $\mathrm{O}_{2}$ in gas packaged products could be due to a number of factors such as 1) oxygen permeability of the packaging material; 2) ability of the product to trap air; and 3) leakage of air through poor sealing [26].

It is evident from the results obtained in this study that mold growth was suppressed when the level of $\mathrm{O}_{2}$ decreased and $\mathrm{CO}_{2}$ increased in the package headspace. These results are in agreement with the previous observations of [27] who reported that the time (days) to detect visible mold growth increased as levels of $\mathrm{CO}_{2}$ increased. The results also indicated that gas packaging can be used to extend the mold free shelf life of products. However, aerobic spoilage i.e., mold growth can still occur in these products, depending on the level of residual oxygen in the package headspace. It is clear that $A$. niger can tolerate and grow in low levels of $\mathrm{O}_{2}$ resulting in mold spoilage. These results confirm the earlier findings of [25] who observed that $A$. niger could grow in a gas packaged bakery product containing $60 \% \mathrm{CO}_{2}$ and low oxygen levels $\left(<1 \% \mathrm{O}_{2}\right)$. [12,28,29] reported that mould can grow in the presence of elevated $\mathrm{CO}_{2}$ if the $\mathrm{O}_{2}$ concentration is sufficient [30] also reported that Xeromyces bisporus, a xerophilic mold, which causes spoilage in food products with a low water activity, grew in an atmosphere of $90 \% \mathrm{CO}_{2}$ and $10 \% \mathrm{O}_{2}$. These authors also reported growth of Aspergillus species in $80 \% \mathrm{CO}_{2}$ and $2.5 \% \mathrm{O}_{2}$. Possibly the only means to reduce headspace oxygen in products to levels inhibitory to mold growth is through the incorporation of oxygen absorbents into the packaged products.

\subsection{Effect of Oxygen Absorbents on Mold Growth}

Oxygen is often a major factor limiting the shelf life of packaged food products. Such products are more susceptible to chemical, mold and bacterial spoilage. For this reason oxygen absorbents are used extensively in the Japanese market to extend the chemical and microbial shelf life of food products [25]. However, few studies have examined the use of oxygen absorbents to control spoilage of bakery goods. Removal of oxygen from the atmosphere of a packaged product using oxygen scavengers may be a viable method to inhibit mold spoilage [25]. Furthermore, the combined use of oxygen absorbent and $\mathrm{CO}_{2}$ enriched atmosphere could be used effectively to control mold growth of $A$. niger and Pencillium species, which appear to be more resistant to elevated levels of $\mathrm{CO}_{2}$ alone. However, this combination means addi- 
tional costs to the processor. Therefore, preliminary studies were done to determine the effectiveness of oxygen absorbents alone to control the growth of common mold contaminant of baked goods.

The effect of oxygen absorbents on the growth of $A$. niger, $P$. notatum, and $P$. expansum in PDA plates packaged in high gas barrier film is shown in Tables 12-14 respectively. In control plates, growth of $A$. niger, $P$. notatum, and $P$. expansum was evident after 1 - 2 days respectively. While the growth of $A$. niger and $P$. notatum was observed after 2 days in plates packaged with one oxygen absorbent, the growth of $P$. expansum was completely inhibited for $>40$ days in plates packaged with only one oxygen absorbent (Tables 12 and 13).

Addition of two oxygen absorbents inhibited the growth of all molds for $>40$ days (Tables 12-14). This

Table 12. Effect of oxygen absorbent on the growth of $A$. niger at $\mathrm{pH} 7.0 \& 25^{\circ} \mathrm{C}$.

\begin{tabular}{ccccc}
\hline \multirow{2}{*}{$\begin{array}{c}\text { Number of } \\
\text { Sachets }\end{array}$} & $\begin{array}{c}\text { Days to visible } \\
\text { growth of } \text { A. niger }\end{array}$ & \multicolumn{3}{c}{${ }^{*}$ Headspace gas composition (\%) } \\
\cline { 3 - 5 } & 1 & 1.0 & 20.4 & 78.6 \\
\hline Air & 2 & 0.98 & 1.26 & 97.7 \\
1 & $\mathrm{CO}_{2}$ & $\mathrm{O}_{2}$ & $\mathrm{~N}_{2}$ \\
2 & ${ }^{* *} \mathrm{NG}$ & 0.1 & 0 & 99.9 \\
\hline
\end{tabular}

All values are the average of triplicates. ${ }^{*}$ At onset of mold growth. ${ }^{* *} \mathrm{NG}=$ No growth $(>40 \mathrm{~d})$.

Table 13. Effect of oxygen absorbent on the growth of $P$. notatum at $\mathrm{pH} 7.0 \& 25^{\circ} \mathrm{C}$.

\begin{tabular}{|c|c|c|c|c|}
\hline \multirow{2}{*}{$\begin{array}{l}\text { Number of } \\
\text { Sachets }\end{array}$} & \multirow{2}{*}{$\begin{array}{l}\text { Days to visible } \\
\text { growth of } \\
P . \text { notatum }\end{array}$} & \multicolumn{3}{|c|}{ "Headspace gas composition (\%) } \\
\hline & & $\mathrm{CO}_{2}$ & $\mathrm{O}_{2}$ & $\mathrm{~N}_{2}$ \\
\hline Air & 1 & 1.4 & 20.6 & 79 \\
\hline 1 & 2 & 0.88 & 1.8 & 97.3 \\
\hline 2 & ${ }^{* *} \mathrm{NG}$ & 0.1 & 0 & 99.9 \\
\hline
\end{tabular}

All values are the average of triplicates. ${ }^{*}$ At onset of mold growth. ${ }^{* *} \mathrm{NG}=$ No growth (>40 d).

Table 14. Effect of oxygen absorbent on the growth of $P$. expansum at $\mathrm{pH} 7.0 \& 25^{\circ} \mathrm{C}$.

\begin{tabular}{ccccc}
\hline \multirow{2}{*}{$\begin{array}{c}\text { Number of } \\
\text { Sachets }\end{array}$} & $\begin{array}{c}\text { Days to visible } \\
\text { growth of } \\
\text { P. expansum }\end{array}$ & \multicolumn{3}{c}{ *Headspace gas composition (\%) } \\
\cline { 3 - 5 } & 1 & 1.5 & 19.5 & 79 \\
\hline Air & $\mathrm{CO}_{2}$ & $\mathrm{O}_{2}$ & $\mathrm{~N}_{2}$ \\
1 & ${ }^{* * *} \mathrm{NG}$ & 0.3 & 1.0 & 98.7 \\
2 & ${ }^{* *} \mathrm{NG}$ & 0.1 & 0 & 99.9 \\
\hline
\end{tabular}

All values are the average of triplicates. ${ }^{*}$ At onset of mold growth. ${ }^{* *} \mathrm{NG}=$ No growth $(>40 \mathrm{~d})$. can be attributed to the effect of lower levels of headspace oxygen. Several studies have reported significant extension in the chemical and microbiological shelf life of intermediate and high moisture bakery products using oxygen absorbent technology [31]. More recently [32] reported that two oxygen absorbents delayed the growth of Aspergillus species and Penicillium species for 30 days while growth was extensive within 4 days in plates packaged with one only oxygen absorbent which is in agreement with our observations.

Comparison between oxygen absorbent technology and gas packaging showed that using oxygen absorbents was a more effective method for controlling the mold growth. These results confirmed the earlier observations of [26] who reported that oxygen absorbents were three times more effective than gas packaging for increasing the mold free shelf life of crusty rolls. These results have also demonstrated that the use of oxygen absorbents can give longer inhibition of mold growth compared to $\mathrm{CO}_{2}$. It can be concluded from this study that the use of oxygen absorbents alone is a simple, effective method of controlling mold growth and extending the mold free shelf life of products.

\section{Conclusion}

In conclusion, these preservatives can be used effectively to retard mold growth. Moreover, thier effectiveness can be enhanced by increasing the presence of the undissociated form of the chemical preservatives which can be achieved at low substrate $\mathrm{pH}$. The use of gas packaging is, without doubt, one of the most exciting interactive packaging technologies available to the food industry. This study shows that MAP comprised of $60 \%$ or $80 \%$ $\mathrm{CO}_{2}$ (balance $\mathrm{N}_{2}$ ) can be used to inhibit mold growth. However, oxygen absorbents, alone can also be used to inhibit mold growth for $>40$ days. Furthermore, the efficiency of oxygen absorbent to inhibit $A$. niger and $P$. notatum can be achieved by using two absorbents in the package. The use of oxygen absorbent technology offers to the food industry a viable alternative to gas flushing for shelf life of foods [29].

\section{REFERENCES}

[1] L. Leistner, "Food Preservation by Combined Methods," Food Research International, Vol. 25, No. 2, 1992, pp. 151-158.

[2] S. Marin, M. E. Guynot, P. Neira, M. Bernado, V. Sanchis and A. J. Ramos, "Risk Assessment of the Use of Sub-Optimal Levels of Weak-Acid Preservatives in the Control of Mould Growth on Bakery Products,” International Journal of Food Microbiology, Vol, 79, No. 3, 2002, pp. 203-211. doi:10.1016/S0168-1605(02)00088-0

[3] E. González-Fandos and J. L. Dominguez, "Effect of 
Potassium Sorbate Washing on the Growth of Listeria Monogcytogenes on Fresh Poultry,” Food Control, Vol 18, No. 7, 2007, pp. 842-846.

doi:10.1016/j.foodcont.2006.04.008

[4] M. E. Guynot, A. J. Ramos and S. S. Marin, "Study of Benzoate, Propionate and Sorbate as Mould Spoilage Inhibitors on Intermediate Moisture Bakery Products of Low pH (4.5 - 5.5)," International Journal of Food Microbiology, Vol. 101, No. 2, 2005, pp.161-168. doi:10.1016/j.ijfoodmicro.2004.11.003

[5] E. Maltini, D. Torreggiani, E. Venir and G. Bertolo "Water Activity and the Preservation of Plant Food," Food Chemistry, Vol. 82, No. 1, 2003, pp. 79-86. doi:10.1016/S0308-8146(02)00581-2

[6] W. J. Scott, "Water Relations of Food Spoilage Microorganisms," Advances in Food Research, Vol. 7, 1957, pp. 83-127. doi:10.1016/S0065-2628(08)60247-5

[7] D. S. Clark and C. P. Lentz, "The Effect of $\mathrm{CO}_{2}$ on the Growth of Slime Producing Bacteria on Fresh Beef," Canadian Institute Food Science Technology Journal, Vol. 2, 1969, pp. 72-75.

[8] K. W. McMillin, "Where Is MAP Going: A Review and Future Potential of Modified Atmosphere Packaging for Meat,” Meat Science, Vol. 80, No. 1, 2008, pp. 43-65. doi:10.1016/j.meatsci.2008.05.028

[9] C. E. Holaday, J. L. Pearson and W. O. Slay, "A New Packaging Method for Peanuts and Pecans," Journal of Food Science, Vol. 44, No. 5, 1979, pp. 1530-1533. doi:10.1111/j.1365-2621.1979.tb06480.x

[10] H. Banks, R. Nickelson and G. Finne, "Shelf-Life Studies on Carbon Dioxide Finfish from the Gulf of México," Journal of Food Science, Vol. 45, No. 2, 1980, pp. 157162. doi:10.1111/j.1365-2621.1980.tb02566.X

[11] R. L. Ory, A. J. Delacca, A. J. Stangleo and H. P. Dupuy, "Storage Quality of Brown Rice as Affected by Packaging with or without $\mathrm{CO}_{2}$," Journal of Food Protection, Vol. 43, 1980, pp. 929-932.

[12] S. Zardetoo, "Effect of Modified Atmosphere Packaging on the Growth of Pencillium aurantiogriseum Isolated from Fresh Filled Pasta,” Food Microbiology, Vol. 22, No. 4, 2005, pp. 367-371. doi:10.1016/j.fm.2004.09.008

[13] I. S. Kotsianis, V. Giannou and C. Tzia, "Production and Packaging of Bakery Products Using MAP Technology," Trends in Foods and Technology, Vol. 13, No. 9-10, 2002, pp. 319-324. doi:10.1016/S0924-2244(02)00162-0

[14] V. Rodriguez and R. Jordano, "Influence of Modified Atmosphere Packaging on the Shelf Life of Prebaked Pizz Dough with and without Preservative Added," Molecular Nutrition and Food Research, Vol. 47, No. 2, 2003, pp. 122-125. doi:10.1002/food.200390022

[15] B. Ooraikul, "Modified Atmosphere Packaging of Bakery Products,” In: B. Ooraikul and E. Stiles, Eds., Modified Atmosphere Packaging of Food, Ellis Horwood, New York, 1991, pp. 49-117.

[16] E. Hoechst, "Sorbic Acid as a Food Preservatives," Flavours, Vol. 5, 1976, pp. 122-126.

[17] J. N. Sofos and F. F. Busta, "Antimicrobial Activity of Sorbate,” Journal of Food Protection, Vol. 44, 1981, pp.
614-621.

[18] M. D. Earle and G. Putt, "Sorbates in Food-A Review," Food Technology in New Zealand, Vol. 9, 1983, pp. 29-35.

[19] M. B. Liewen and E. H. Marth, "Growth and Inhibition of Microorganism in the Presence of Sorbic Acid,” Journal of Food Protection, Vol. 48, 1985, pp. 364-375.

[20] F. J. Bandelin, "The Effect of pH on the Efficacy of Various Mold Inhibiting Compounds," Journal of the American Pharmaceutical Assocation, Vol. 47, 1958, pp. 691694.

[21] J. N. Sofos, "Sorbate Food Preservatives,” CRC Press, Inc., Boca Raton, 1989, pp. 33-192.

[22] L. Ray and L. B. Bullerman, "Preventing Growth of Potentially Toxic Molds Using Antifungal Agents,” Journal of Food Protection, Vol. 45, 1982, pp. 953-963.

[23] D. A. L. Seiler, "The Use of Antimould Agents in Bread," Report No. 64, British Baking Industries Research Association, 1962, pp. 6-10.

[24] K. M. Acott and T. P. Labuza, "Inhibition of Aspergillus Niger in an Intermediate Moisture Food System,” Journal of Food Science, Vol. 40, No. 1, 1975, pp. 137-139. doi:10.1111/j.1365-2621.1975.tb03755.x

[25] J. P. Smith, B. Ooraikul, W. J. Koersen, E. D. Jackson and R. A. Lawrence, "Novel Approach to Oxygen Control in Modified Atmosphere Packaging of Bakery Products,” Food Microbiology, Vol. 3, No. 4, 1986, pp. 315320. doi:10.1016/0740-0020(86)90015-8

[26] J. P. Smith, "Modified Atmosphere Packaging for Bakery Products," American Institute of Baking, Vol. 16, 1994, pp. 1-9.

[27] D. A. L. Seiler, "Modified Atmosphere Packaging of Bakery Products," In: A. L. Brody, Ed., Controlled/ Modified Atmosphere/Vacuum Packaging of Foods, Food and Nutrition Press, Trumball, 1989, pp. 119-133.

[28] W. O. Ellis, J. P. Smith, B. K. Simpson, S. Khanizadeh and J. H. Oldhem, "Control of Growth and Aflatoxin Production of Aspergillus flvus under Modified Atmosphere Packaging (MAP) Conditions,” Food Microbilogy, Vol. 10, No. 1, 1993, pp. 9-21. doi:10.1006/fmic.1993.1002

[29] M. E. Guynot, S. Marin, V. Sanchis and A. J. Ramos, "Modified Atmosphere Packaging for Prevention of Mould Spoilage of Bakery Products with Different $\mathrm{pH}$ and Water Activity Levels," Journal of Food Protection, Vol. 66, No. 10, 2003, pp. 1864-1872.

[30] H. Dallyn and J. R. Everton, "The Xerophilic Mould, Xeromyces bisporus, as a Spoilage Organism," Journal of Food Technology, Vol. 4, No. 4, 2007, pp. 339-403. doi:10.1111/j.1365-2621.1969.tb01535.X

[31] Y. Abe and Y. Kondoh, “Oxygen Absorbers,” In: A. L. Brody, Ed., Controlled/Modified Atmosphere/Vacuum Packaging of Foods, Food and Nutrition Press, Trumball, 1989, pp. 149-158.

[32] E. M. Powers and D. Berkowiz, "Efficacy of an Oxygen Scavenge to Modify the Atmosphere and Prevent Mould Growth on Meal, Ready-to-Eat Pouched Breads,” Journal of Food Protection, Vol. 53, 1990, pp. 767-771. 